OPEN ACCESS

Edited by: Soumitra Paul,

University of Calcutta, India

Reviewed by:

Dimah Habash,

SECUREWHEAT Consultancy, UK

Ümit Barş Kutman,

Konya Food and Agriculture

University, Turkey

${ }^{*}$ Correspondence:

Guohua Mi

miguohua@cau.edu.cn

Specialty section: This article was submitted to Plant Nutrition,

a section of the journal

Frontiers in Plant Science

Received: 25 February 2016 Accepted: 06 May 2016

Published: 24 May 2016

Citation:

MuX, Chen Q, Chen F, Yuan L and MiG (2016) Within-Leaf Nitrogen

Allocation in Adaptation to Low Nitrogen Supply in Maize during

Grain-Filling Stage.

Front. Plant Sci. 7:699.

doi: 10.3389/fpls.2016.00699

\section{Within-Leaf Nitrogen Allocation in Adaptation to Low Nitrogen Supply in Maize during Grain-Filling Stage}

\author{
Xiaohuan Mu, Qinwu Chen, Fanjun Chen, Lixing Yuan and Guohua Mi* \\ Center for Resources, Environment and Food Security, College of Resources and Environmental Science, China Agricultural \\ University, Beijing, China
}

Nitrogen $(\mathrm{N})$ plays a vital role in photosynthesis and crop productivity. Maize plants may be able to increase physiological $\mathrm{N}$ utilization efficiency (NUtE) under low- $\mathrm{N}$ stress by increasing photosynthetic rate $\left(P_{n}\right)$ per unit leaf $\mathrm{N}$, that is, photosynthetic $\mathrm{N}$-use efficiency (PNUE). In this study, we analyzed the relationship between PNUE and $N$ allocation in maize ear-leaves during the grain-filling stage under low $\mathrm{N}$ (no $\mathrm{N}$ application) and high $\mathrm{N}$ (180 $\mathrm{kg} \mathrm{N} \mathrm{ha}^{-1}$ ) in a 2-year field experiment. Under low $\mathrm{N}$, grain yield decreased while NUtE increased. Low-N treatment reduced the specific $\mathrm{N}$ content of ear leaves by $38 \%$ without significant influencing $P_{\mathrm{n}}$, thereby increasing PNUE by $54 \%$. Under low- $\mathrm{N}$ stress, maize plants tended to invest relatively more $\mathrm{N}$ into bioenergetics to sustain electron transport. In contrast, $\mathrm{N}$ allocated to chlorophyll and light-harvesting proteins was reduced to control excess electron production. Soluble proteins were reduced to shrink the $\mathrm{N}$ storage reservoir. We conclude that optimization of $\mathrm{N}$ allocation within leaves is a key adaptive mechanism to maximize $P_{\mathrm{n}}$ and crop productivity when $\mathrm{N}$ is limited during the grain-filling stage in maize under low- $\mathrm{N}$ conditions.

\begin{abstract}
Keywords: bioenergetics, light harvesting, phosphoenolpyruvate carboxylase, photosynthetic rate, photosynthetic nitrogen use efficiency, pyruvate orthophosphate dikinase, ribulose-1,5-bisphosphate carboxylase, thylakoid nitrogen
\end{abstract}

\section{INTRODUCTION}

In modern crop production systems, nitrogen $(\mathrm{N})$ plays a vital role in yield formation; it is the mineral element required in the greatest amounts by plants, and is often the growth-limiting nutrient. $\mathrm{N}$ is a fundamental constituent of many cell components. In leaves, forms of $\mathrm{N}$ include soluble components such as nitrates, amino acids and proteins, and insoluble components in cell walls, membranes and other structures. $\mathrm{N}$ used in the photosynthetic apparatus can be divided into two categories, namely, that associated with photosynthetic enzymes and thylakoid $\mathrm{N}$. The main photosynthetic enzymes, ribulose-1,5-bisphosphate carboxylase (Rubisco), phosphoenolpyruvate carboxylase (PEPC) and pyruvate orthophosphate dikinase (PPDK), are involved in carbon reduction reactions and are the most abundant enzymes in photosynthesis (Tazoe et al., 2005). Thylakoid $\mathrm{N}$ is distributed between two types of proteins: (1) proteins related to bioenergetics, including Cyt $b / f$ and $\mathrm{CF}_{1} / \mathrm{CF}_{0}$ involved in electron transport and photophosphorylation, and (2) light-harvesting proteins, such as photosystem I (PSI), photosystem II (PSII), and light-harvesting complex II (LHCII) proteins, that are associated with the light reactions of photosynthesis (Makino et al., 1997; Takashima et al., 2004; Tazoe et al., 2005; Uribelarrea et al., 2009). When grown under high light, $\mathrm{C}_{3}$ leaves typically invested $58 \%$ of leaf $\mathrm{N}$ to soluble protein (about $40 \%$ of which is 
Rubisco) and 22\% to thylakoids (Evans, 1989a; Poorter and Evans, 1998; Makino et al., 2003). While in $\mathrm{C}_{4}$ plant, about $45 \%$ leaf $\mathrm{N}$ partitioned into soluble protein (about $20 \%$ of which is Rubisco) and $28 \%$ into thylakoids (Makino et al., 2003; Ghannoum et al., 2005; Tazoe et al., 2005). And about $80 \%$ of thylakoids $\mathrm{N}$ in $\mathrm{C}_{3}$ plants and $75 \%$ of thylakoids $\mathrm{N}$ in $\mathrm{C}_{4}$ plants allocated in light-harvesting proteins, the other allocated in bioenergetics (Evans, 1989b; Makino et al., 2003). A strongly positive correlation has been widely reported between photosynthetic capacity and $\mathrm{N}$ content per unit leaf area (Makino et al., 2003; Takashima et al., 2004; Tazoe et al., 2005). N supply thus has substantial effects on plant growth and development and yield formation.

Under $\mathrm{N}$-limited conditions, maize plants increased $\mathrm{N}$ use efficiency by increasing $\mathrm{N}$ uptake efficiency (NUpE) and/or $\mathrm{N}$ utilization efficiency (NUtE; Moll et al., 1982; Hirel et al., 2007). Efficient $\mathrm{N}$ acquisition is believed to rely on a large and deep root system (Lawlor, 2002; Wang et al., 2005; Mi et al., 2010; Lynch, 2013). NUtE, which is defined as grain yield produced per unit of plant N (Moll et al., 1982; Hirel et al., 2007), is an indicator of how plant $\mathrm{N}$ is used for photosynthetic production. On a wholeplant level, an optimal $\mathrm{N}$ distribution in the plant canopy may improve photosynthesis without additional $\mathrm{N}$ input (Dwyer and Stewart, 1986; Drouet and Bonhomme, 1999; Hikosaka, 2014). How $\mathrm{N}$ can be efficiently used to produce as much photosynthate in single leaves, especially under N-limited conditions, is less clear. Photosynthetic $\mathrm{N}$ use efficiency (PNUE), the rate of photosynthesis per unit leaf $\mathrm{N}$, is increased under low-N stress (Sage and Pearcy, 1987; Ghannoum et al., 2005; Uribelarrea et al., 2009; Hawkesford, 2012). In a recent field study, an N-efficient maize genotype was found to have a higher PNUE than an inefficient one (Chen et al., 2014). In spite of these findings, the underlying physiological mechanism of photosynthetic $\mathrm{N}$ use efficiency remains unclear.

In general, $\mathrm{C}_{4}$ plants exhibit a greater PNUE than $\mathrm{C}_{3}$ plants (Brown, 1978; Schmitt and Edwards, 1981; Sage and Pearcy, 1987, 2000; Makino et al., 2003). This higher PNUE is mainly because $\mathrm{C}_{4}$ plants can eliminate photorespiration by increasing $\mathrm{CO}_{2}$ levels in the vicinity of Rubisco. In maize, a $\mathrm{C}_{4}$ plant, the $\mathrm{N}$ cost for $\mathrm{C}_{4}$-cycle enzymes (PPDK and PEPC) is not large; in addition, the lower amount of Rubisco in maize allows a greater $\mathrm{N}$ investment to be made in the thylakoid components compared with rice, a $\mathrm{C}_{3}$ plant (Makino et al., 2003). And NADP-malic enzyme (ME) $\mathrm{C}_{4}$ grasses have a higher PNUE and NUE than NAD-ME $\mathrm{C}_{4}$ grasses (Ghannoum et al., 2005). The main reason is that they have less leaf $\mathrm{N}$ and soluble protein but a faster $k_{\text {cat }}$ of Rubisco in NADP-malic enzyme (ME) $\mathrm{C}_{4}$ grasses (Ghannoum et al., 2005).

In maize, around $80-100 \%$ of dry matter for grain yield formation is contributed by post-silking photosynthesis (Tollenaar and Lee, 2006; Chen et al., 2013, 2014; Kosgey et al., 2013; Antonietta et al., 2014). During the post-silking period, the maintenance of a high rate of whole-plant photosynthesis is difficult, as $\mathrm{N}$ is continuously remobilized from the leaves, especially under $\mathrm{N}$-limited conditions. An increase in PNUE would potentially resolve this problem (Chen et al., 2014). Most of the research on PNUE has been conducted at seedling stage
(Sugiharto et al., 1990; McCullough et al., 1994; Makino et al., 2003), less is known about the physiological determinants of PNUE during the grain-filling stage under field conditions. The aim of this study was consequently to uncover the relationship between within-leaf $\mathrm{N}$ allocation and PNUE.

\section{MATERIALS AND METHODS}

\section{Plant Materials and Growth Conditions}

Field experiments were conducted in 2013 and 2014 at the Shangzhuang Experimental Station, China Agricultural University, Beijing, China $\left(116^{\circ} 11^{\prime} \mathrm{N}, 40^{\circ} 8^{\prime} \mathrm{E}\right)$. The field soil was a typical Ustochrept soil with the following physical and chemical characteristics $(0-20 \mathrm{~cm})$ at the start of the experiment: $92.4 \mathrm{~kg} \mathrm{~N}$ ha $^{-1} \mathrm{CaCl}_{2}$-extracted mineral $\mathrm{N}\left(\mathrm{N}_{\min }\right), 16.2 \mathrm{mg}$ $\mathrm{kg}^{-1}$ available phosphorus (Olsen-P), $122.6 \mathrm{mg} \mathrm{kg}^{-1}$ ammonium acetate extractable potassium (K), $11.6 \mathrm{~g} \mathrm{~kg}^{-1}$ organic matter, and a $\mathrm{pH}\left(\mathrm{H}_{2} \mathrm{O}\right)$ of 8.0. Before plowing, the field was irrigated, plowed (immediately before plowing) and sprinkled with a base fertilizer consisting of $135 \mathrm{~kg} \mathrm{P}_{2} \mathrm{O}_{5} \mathrm{ha}^{-1}$ [as superphosphate (Ca $\left.\left.\left(\mathrm{H}_{2} \mathrm{PO}_{4}\right)_{2} \cdot \mathrm{H}_{2} \mathrm{O}\right)\right]$ and $75 \mathrm{~kg} \mathrm{~K}_{2} \mathrm{O} \mathrm{ha}^{-1}$ (as $\left.\mathrm{K}_{2} \mathrm{SO}_{4}\right)$. Additional $\mathrm{N}$ was applied at two different treatment levels: $180 \mathrm{~kg} \mathrm{~N} \mathrm{ha}^{-1}(\mathrm{HN})$ and no $\mathrm{N}$ application (LN). For the HN treatments, $30 \%$ of the $\mathrm{N}$ fertilizer was applied before sowing and the remaining at the V6 stage (six expanded leaves). In the previous research conducted in the same field, $\mathrm{N}$ application at $180 \mathrm{~kg} \mathrm{ha}^{-1}$ was found sufficient to achieve the maximum yield (data not shown). At harvest, the residual soil $\mathrm{N}_{\min }(0-20 \mathrm{~cm})$ was 52 and $38 \mathrm{~kg} \mathrm{~N} \mathrm{ha}^{-1}$ in 2013 and 2014, respectively.

The experiment consisted of a randomized block design with four replicates, with each plot $15 \mathrm{~m}$ long and $9 \mathrm{~m}$ wide. Zhengdan 958, the most popular commercial hybrid across North and Northeast China, was sown on April 28, 2013, and April 29, 2014, and was harvested on September 7 and September 3 of 2013 and 2014, respectively. The plots were over-seeded using a hand planter, and then thinned at the seeding stage to 60,000 plants $\mathrm{ha}^{-1}$. Distances between rows and plants were 60 and $28 \mathrm{~cm}$, respectively. Plots were kept free of weeds, insects and diseases during the growth season. During 2013, rainfall was adequate during the entire growth period and no irrigation was applied. Because a severe drought occurred during the silking stage in 2014 , irrigation was applied during that period to ensure normal plant growth.

\section{Gas Exchange and Chlorophyll Fluorescence Parameters Measurements}

At the silking stage, six plants with the same silking date were tagged. At 20 and 23 days after silking in 2013 and 2014, respectively, the ear-leaf net photosynthetic rate $\left(P_{\mathrm{n}}\right)$ of six tagged plants per plot was determined. The average of the $P_{\mathrm{n}}$ values of the six plants in each plot was taken as a replicate. $P_{\mathrm{n}}$ was measured with a portable photosynthesis system (Li6400; LI-COR, Lincoln, NE, USA) coupled to a standard red/blue LED broadleaf cuvette (6400-02B; LI-COR) and a $\mathrm{CO}_{2}$ mixer (6400-01; LI-COR) at a light intensity of $1,600 \mu \mathrm{mol} \mathrm{m} \mathrm{m}^{-2} \mathrm{~s}^{-1}$. Measurements were obtained at a leaf temperature of $30 \pm 0.5^{\circ} \mathrm{C}$ 
and a $\mathrm{CO}_{2}$ concentration inside the chamber of $400 \pm 1 \mu \mathrm{mol}$ $\mathrm{CO}_{2}$ (mol air) ${ }^{-1}$ (Ding et al., 2005a; Uribelarrea et al., 2009). The following day, the same plants that had been used for the photosynthetic rate measurements in each plot were used to obtain chlorophyll fluorescence using Li6400. The plants were continuously illuminated at least $1 \mathrm{~h} . \mathrm{CO}_{2}$ concentration inside the chamber was $400 \mu \mathrm{mol} \mathrm{mol}^{-1}$ and holding incident irradiance at $1600 \mu \mathrm{mol} \mathrm{m} \mathrm{m}^{-2} \mathrm{~s}^{-1}$. The actual quantum yield of PSII photochemistry ( PPSII) and electron transport rate (ETR, $\mu \mathrm{mol} \mathrm{e}^{-} \mathrm{s}^{-1} \mathrm{~m}^{-2}$ ) were calculated as defined by Ding et al. (2005b). Leaf area was calculated according to Sanderson et al. (1981) as leaf length $\times$ maximum width $\times \mathrm{k}$, where $\mathrm{k}$ is a shape factor equal to 0.75 (Birch et al., 2003).

\section{Biochemical Measurements}

After measurement of chlorophyll fluorescence parameters, two leaves per plot were removed, immediately frozen in liquid $\mathrm{N}_{2}$ and stored at $-80^{\circ} \mathrm{C}$ for subsequent analysis. Two additional leaves were dried at $65^{\circ} \mathrm{C}$ to a constant weight. After removal of midribs, the dried leaves were thoroughly ground and then analyzed for total N with an NC analyzer (Vario EL III; Elementar, Hanau, Germany). Specific leaf N (SLN) was calculated as N content per unit leaf area.

Rubisco, PEPC, and PPDK contents of frozen leaves were determined using the method of Makino et al. (2003) with minor modifications. Using a chilled mortar and pestle, the frozen leaves were homogenized in extraction buffer containing $0.2 \mathrm{mM}$ EDTA-Na, $10 \mathrm{mM}$ dithiothreitol, $2 \mathrm{mM}$ iodoacetic acid, $0.1 \%$ Triton $\mathrm{X}-100$ and $100 \mathrm{mM}$ Tris- $\mathrm{HCl}$ at $\mathrm{pH}$ 6.8. The homogenate was centrifuged at $12,000 \mathrm{~g}$ for $20 \mathrm{~min}$ at $4^{\circ} \mathrm{C}$. A portion of the supernatant was used for determination of total soluble protein content using a protein assay kit based on the Bradford method (Bio-Rad Protein Assay; Bio-Rad, CA, USA). The supernatant was treated with double-strength loading buffer [5\% (w/v) lithium dodecyl sulfate, $5 \% \beta$-mercaptoethanol, $0.1 \%$ bromophenol blue, $5 \%$ glycerol and $25 \mathrm{mM}$ Tris- $\mathrm{HCl}$ at $\mathrm{pH}$ 6.8], heated at $100^{\circ} \mathrm{C}$ for $5 \mathrm{~min}$, and analyzed by sodium dodecyl sulfate (SDS)-polyacrylamide gel electrophoresis. Rubisco, PEPC, and PPDK were determined spectrophotometrically by formamide extraction of their Coomassie-Brilliant-Blue-R-250stained bands, which corresponded to $99 \mathrm{kDa}$ for PEPC (Uedan and Sugiyama, 1976), $94 \mathrm{kDa}$ for PPDK (Sugiyama, 1973) and 52 and $15 \mathrm{kDa}$ for Rubisco (Makino et al., 2003). Protein concentration was calculated using bovine serum albumin as a standard (Makino et al., 1986; Fukayama et al., 2001). Cell wall biomass and $\mathrm{N}$ content were analyzed according to Onoda et al. (2004) with modifications. The pellet was resuspended with Tris- $\mathrm{HCl}$ buffer containing 3\% (w/v) SDS, incubated at $90^{\circ} \mathrm{C}$ for $5 \mathrm{~min}$, and then centrifuged at $2,500 \mathrm{~g}$ for $5 \mathrm{~min}$. This procedure was repeated eight times. To remove small amounts of cytoplasmic protein contamination, the pellet was washed six times with $0.2 \mathrm{M} \mathrm{KOH}$ followed by centrifugation at 2,500 $\mathrm{g}$ for $5 \mathrm{~min}$. These procedures removed proteins weakly bound to cell walls, leaving behind only tightly bound (structural) proteins. After six washes with distilled water and six washes with ethanol, the tube containing the pellet was dried in an oven at $75^{\circ} \mathrm{C}$ to a constant weight. After drying, the cell wall materials were weighed and their total $\mathrm{N}$ concentrations were determined using the NC analyzer.

Chlorophyll (Chl) was extracted from leaf disks with acetone and ethanol. The absorbance of the extracts was spectrophotometrically measured at 645 and $663 \mathrm{~nm}$ (Porra et al., 1989). Nitrate was extracted from fresh leaves with distilled water and quantified following Cataldo et al. (1975). Free amino acids were determined according to Moore (1968).

Thylakoid membranes were prepared according to standard methods (Zhang et al., 1999; Peng et al., 2006). The leaves were homogenized with a chilled mortar and pestle in an ice-cold isolation buffer containing $400 \mathrm{mM}$ sucrose, $50 \mathrm{mM}$ HEPES$\mathrm{KOH}$ ( $\mathrm{pH} 7.8$ ), $10 \mathrm{mM} \mathrm{NaCl}$, and $2 \mathrm{mM} \mathrm{MgCl}_{2}$ and filtrated through four layers of cheesecloth. The filtrate was centrifuged at $5000 \mathrm{~g}$ for $10 \mathrm{~min}$. The thylakoid pellets were washed with isolation buffer, recentrifuged, and suspended in isolation buffer. The thylakoid membrane pellets were dried in an oven at $75^{\circ} \mathrm{C}$ to a constant weight. After drying, the thylakoid membrane was weighed and their total $\mathrm{N}$ concentrations were determined using the NC analyzer.

\section{Yield, N Uptake and Physiological N Utilization Efficiency (NUtE)}

At silking and physiological maturity, five consecutive plants per plot were cut at the soil surface and separated into leaves, stalks (including leaf sheaths and tassels), husks/cobs and grains. All samples were dried at $65^{\circ} \mathrm{C}$ to a constant weight. The silking stage was considered to be when $50 \%$ of the ears in a plot attained silking, whereas physiological maturity corresponded to the stage when a black layer was visible at the grain base in $50 \%$ of the ears. Dry samples were weighed and ground to a powder; N concentrations were determined using the semi-micro-Kjeldahl method. NUtE values were calculated as grain dry weight divided by total $\mathrm{N}$ content per plant. At physiological maturity, two rows of plants in each plot were harvested for determination of grain yield. Grain yield was standardized to $14 \%$ moisture.

\section{Calculations}

Thylakoid $\mathrm{N}$ can be divided into two categories according to its allocation: (1) bioenergetics (associated with the electron transport chain and photophosphorylation) and (2) lightharvesting (involved in PSI, PSII, and LHC). N associated with light harvesting $\left(\mathrm{N}_{\mathrm{h}}\right)$ was calculated assuming $37 \mathrm{~mol} \mathrm{~mol}^{-1} \mathrm{Chl}$ (Ghannoum et al., 2005), while $\mathrm{N}$ in bioenergetics $\left(\mathrm{N}_{\mathrm{b}}\right)$ was calculated as $\mathrm{N}_{\mathrm{TH}}$ minus $\mathrm{N}_{\mathrm{h}}$. $\mathrm{N}$ allocated to Rubisco, PEPC, PPDK, and soluble protein was calculated assuming $16 \% \mathrm{~N}$ in proteins (Ghannoum et al., 2005).

\section{Statistical Analysis}

Data across $\mathrm{N}$ treatments and years were first pooled and subjected to a two-factor analysis of variance using the ANOVA procedure implemented in SPSS Statistics 17.0 (SPSS, Inc., Chicago, IL, USA). Differences were compared using the least significant difference test at a 0.05 level of probability. It is found that the $\mathrm{N}$ treatment $\times$ Year interaction effect is not significant for almost all the measured parameters (Supplemental Table S1). 
Therefore, the 2 years' data was averaged for each parameter. All figures were constructed using GraphPad Prism 5 (GraphPad Software Inc., 2007).

\section{RESULTS}

\section{Effect of N Supply on Grain Yield, N Accumulation, NUtE, $P_{\mathrm{n}}$, and PNUE}

Under LN stress, grain yield and total $\mathrm{N}$ uptake decreased by 32 and 57\%, respectively (Table 2). In contrast, physiological N utilization efficiency (NUtE) increased by $57 \%$ compared with HN treatment.

For the ear-leaf, LN treatment significantly affected SLN, but had little influence on $P_{\mathrm{n}}$ (Table 3). As a calculated result, PNUE was increased in the LN treatment. Compared with the $\mathrm{HN}$ treatment, SLN was 38\% lower and PNUE was 54\% higher under the LN treatment.

\section{Effect of N Supply on N Investment into Soluble-N Components}

Nitrate content in LN-treated plants was higher than in the HN treatment (Table 4). Leaf nitrate content was very low, accounting for about $1 \%$ of total leaf $\mathrm{N}$ (Figure 3 ). The amount of $\mathrm{N}$ in amino acids was $51 \%$ lower under the $\mathrm{LN}$ treatment compared with $\mathrm{HN}$ treatment (Table 4).

Soluble protein content was almost twofold less in plants grown under the LN treatment conditions (Table 4). Low $\mathrm{N}$ reduced the contents of Rubisco (including large and small subunits), PEPC and PPDK per unit leaf area by 52.0, 54.2, and $51.0 \%$, respectively (Table 4, Figure 4; Supplementary Figure S1). When calculated on the basis of leaf N, Rubisco, PEPC, and PPDK concentrations per leaf $\mathrm{N}$ were, respectively, 24, 28, and 23\% lower under $\mathrm{LN}$ treatment than under $\mathrm{HN}$ treatment (data not shown).

\section{Effect of N Supply on the N Allocation into Structure-N Components}

$\mathrm{N}_{\mathrm{TH}}$ and $\mathrm{N}_{\mathrm{h}}$ expressed per unit leaf area were 44.6 and $47.4 \%$ lower, respectively, in the $\mathrm{LN}$ treatment compared with $\mathrm{HN}$ (Table 4; Figure 4). There was no significant difference in $\mathrm{N}_{\mathrm{b}}$ between $\mathrm{N}$ treatments. Compared with $\mathrm{HN}$ treatment, $\mathrm{N}_{\mathrm{h}} / \mathrm{N}_{\mathrm{TH}}$ was reduced and $\mathrm{N}_{\mathrm{b}} / \mathrm{N}_{\mathrm{TH}}$ was increased under $\mathrm{LN}$ treatment, while $\mathrm{N}_{\mathrm{TH}}$ /SLN was no significant difference (Figures 1 and 4).

Ear-leaf cell-wall $\mathrm{N}$ content $\left(\mathrm{N}_{\mathrm{cW}}\right)$ was $35 \%$ lowers in $\mathrm{LN}$ compared with the HN treatment (Table 4). However, the fraction of cell wall biomass was higher in the LN treatment (Figure 2).

\section{Effect of N Supply on the Leaf N Budget}

The percentage of leaf $\mathrm{N}$ allocated to different $\mathrm{N}$ components is summarized in Figure 3. Relative to HN treatment levels, the LN treatment significantly reduced the percentage of $\mathrm{N}$ allocated to soluble proteins (including Rubisco, PEPC, and PPDK) and lightharvesting proteins. Among the three major enzymes-Rubisco, PEPC, and PPDK - the percentage of leaf $\mathrm{N}$ allocated to Rubisco,
PEPC, and PPDK declined 24, 28, and 23\%, respectively, under LN treatment. In contrast, $\mathrm{N}$ allocation to bioenergetics processes increased by $62.5 \%$ under low $\mathrm{N}(4.0 \%$ at $\mathrm{HN}$ and $6.5 \%$ at $\mathrm{LN})$.

TABLE 1 | Abbreviations, symbols used and their units used in the text.

\begin{tabular}{|c|c|c|}
\hline Symbol & Definition & Units \\
\hline 3-PGA & 3-phosphoglyceric acid & - \\
\hline CA & Carbonic anhydrase & - \\
\hline Chl & Chlorophyll & $\mu \mathrm{mol} \mathrm{m}{ }^{-2}$ \\
\hline Chl a & Chlorophyll a & $\mu \mathrm{mol} \mathrm{m} \mathrm{m}^{-2}$ \\
\hline Chl $b$ & Chlorophyll $b$ & $\mu \mathrm{mol} \mathrm{m}{ }^{-2}$ \\
\hline $\mathrm{Fd}$ & Ferredoxin & - \\
\hline gbs & Bundle-sheath conductance & - \\
\hline $\mathrm{LHCll}$ & Light harvest complex & - \\
\hline LUS & Rubisco large subunits & - \\
\hline Mal & Malate & - \\
\hline $\mathrm{MDH}$ & Malate dehydrogenase & - \\
\hline $\mathrm{N}$ & Nitrogen & - \\
\hline $\mathrm{Na}$ & Nitrogen in amino acids & $\mathrm{mg} \mathrm{m}^{-2}$ \\
\hline $\mathrm{N}_{\mathrm{b}}$ & Nitrogen in bioenergetic protein & $\mathrm{mg} \mathrm{m}^{-2}$ \\
\hline $\mathrm{N}_{\mathrm{b}} / \mathrm{N}_{\mathrm{TH}}$ & $\begin{array}{l}\text { Fraction of thylakoid nitrogen } \\
\text { allocated to bioenergetics }\end{array}$ & $\%$ \\
\hline $\mathrm{N}_{\mathrm{CW}}$ & Nitrogen in cell wall & $\mathrm{mg} \mathrm{m}^{-2}$ \\
\hline $\mathrm{N}_{\mathrm{h}}$ & $\begin{array}{l}\text { Nitrogen in light-harvesting } \\
\text { protein }\end{array}$ & $\mathrm{mg} \mathrm{m}^{-2}$ \\
\hline $\mathrm{N}_{\mathrm{h}} / \mathrm{N}_{\mathrm{TH}}$ & $\begin{array}{l}\text { Fraction of thylakoid nitrogen } \\
\text { allocated to light-harvesting } \\
\text { protein }\end{array}$ & $\%$ \\
\hline ns & Not significant & - \\
\hline $\mathrm{N}_{\mathrm{S}}$ & $\begin{array}{l}\text { Nitrogen in the soluble proteins } \\
\text { other than PEPC, PPDK, and } \\
\text { Rubisco }\end{array}$ & $\mathrm{mg} \mathrm{m}^{-2}$ \\
\hline $\mathrm{N}_{\mathrm{T}}$ & Nitrogen in thylakoid & $\mathrm{mg} \mathrm{m}^{-2}$ \\
\hline $\mathrm{N}_{\mathrm{TH}} / \mathrm{N}$ & $\begin{array}{l}\text { Fraction of nitrogen allocated to } \\
\text { thylakoid }\end{array}$ & $\%$ \\
\hline OAA & Oxaloacetic acid & - \\
\hline PC & Plastocyanin & - \\
\hline PEPC & $\begin{array}{l}\text { Phosphoenolpyruvate } \\
\text { carboxylase }\end{array}$ & - \\
\hline$P_{\mathrm{n}}$ & Photosynthetic rate & $\begin{array}{l}\mu \mathrm{mol} \mathrm{CO}_{2} \mathrm{~m}^{-2} \\
\mathrm{~s}^{-1}\end{array}$ \\
\hline$P_{\max }$ & Maximum photosynthetic rate & $\begin{array}{l}\mu \mathrm{mol} \mathrm{CO} \mathrm{CO}_{2} \mathrm{~m}^{-2} \\
\mathrm{~s}^{-1}\end{array}$ \\
\hline PNUE & $\begin{array}{l}\text { Photosynthetic nitrogen use } \\
\text { efficiency }\end{array}$ & $\begin{array}{l}\mu \mathrm{mol} \mathrm{CO}_{2} \mathrm{~g}^{-1} \mathrm{~N} \\
\mathrm{~s}^{-1}\end{array}$ \\
\hline PPDK & $\begin{array}{l}\text { Pyruvate orthophosphate } \\
\text { dikinase }\end{array}$ & - \\
\hline$P Q$ & Plastoquinone & - \\
\hline PSI & Photosystem I & - \\
\hline PSII & Photosystem II & - \\
\hline Pyr & Pyruvate & - \\
\hline Rubisco & $\begin{array}{l}\text { Ribulose 1,5-bisphosphate } \\
\text { carboxylase/oxygenase }\end{array}$ & - \\
\hline RuBP & Ribulose 1,5-bisphosphate & - \\
\hline SLN & Specific leaf nitrogen & $\mathrm{g} \mathrm{m}^{-2}$ \\
\hline SSU & Rubisco small subunits & - \\
\hline Triose-P & Triose-phosphate & - \\
\hline
\end{tabular}


Unexpectedly, the allocation of $\mathrm{N}$ to nitrate and the remaining $\mathrm{N}$ components were also higher under low $\mathrm{N}$. The proportion of $\mathrm{N}$ in amino acid was lower $22 \%$ under LN treatment. The percentage of $\mathrm{N}$ allocated to cell walls was similar between $\mathrm{N}$ treatments.

\section{Effect of N Supply on Chlorophyll (Chl) and Chlorophyll Fluorescence}

The contents of Chl, Chl $a$ and Chl $b$ per unit leaf area were reduced by $\mathrm{LN}$ treatment (Figure 5). Chl content decreased by $47 \%$ in LN leaves than in $\mathrm{HN}$ leaves; conversely, the Chl $a / b$ ratio was significantly higher in LN leaves than in HN leaves

TABLE 2 | Effect of nitrogen (N) supply on grain yield, $\mathrm{N}$ accumulation at maturity and $\mathrm{N}$ utilization efficiency (NUtE).

\begin{tabular}{lccc}
\hline $\mathbf{N}$ treatments & $\begin{array}{c}\text { Grain yield } \mathbf{( k g} \\
\left.\mathbf{h a}^{-\mathbf{1}}\right)\end{array}$ & $\begin{array}{c}\mathbf{N} \text { accumulation } \\
\text { in maturity }(\mathbf{g} \\
\left.\text { plant }^{-\mathbf{1}}\right)\end{array}$ & $\begin{array}{c}\text { NUtE [g grain } \\
\mathbf{( g N}^{-\mathbf{1}} \mathbf{]}\end{array}$ \\
\hline $\mathrm{HN}$ & $9827 \mathrm{a}$ & $4.49 \mathrm{~b}$ & $36.8 \mathrm{~b}$ \\
$\mathrm{LN}$ & $6710 \mathrm{~b}$ & $1.94 \mathrm{a}$ & $57.9 \mathrm{a}$
\end{tabular}

Data are the means for the 2 years. Numbers followed by different letters indicate significant differences $(P<0.05)$.

TABLE 3 | Effect of nitrogen (N) supply on net photosynthetic rate $\left(P_{n}\right)$, specific leaf $N$ (SLN) and photosynthetic $N$ use efficiency (PNUE) in maize ear-leaves during the grain-filling stage.

\begin{tabular}{|c|c|c|c|}
\hline $\mathrm{N}$ treatments & $\begin{array}{c}P_{\mathrm{n}} \mu \mathrm{mol} \mathrm{CO} \mathrm{CO}_{2} \\
\mathrm{~m}^{-2} \mathrm{~s}^{-1}\end{array}$ & SLN g m$^{-2}$ & $\begin{array}{c}\text { PNUE } \mu \mathrm{mol} \\
\mathrm{CO}_{2} \mathrm{~g} \mathrm{~N}^{-2} \mathrm{~s}^{-1}\end{array}$ \\
\hline $\mathrm{HN}$ & $31.6 a$ & $2.48 a$ & $12.98 \mathrm{c}$ \\
\hline LN & $30.5 a$ & $1.55 \mathrm{c}$ & $19.69 a$ \\
\hline
\end{tabular}

$P_{\mathrm{n}}$ was measured using a light intensity of $1600 \mu \mathrm{mol} \mathrm{m} \mathrm{m}^{-2} \mathrm{~s}^{-1}$. Measurements were made on ear-leaves between 09:00 and 12:00. Data are the means for the 2 years. Numbers followed by different letters indicate significant differences $(P<0.05)$.

TABLE 4 | Effect of nitrogen $(\mathrm{N})$ supply on the contents of $\mathrm{N}$ compounds in maize ear-leaves during the grain-filling stage.

\begin{tabular}{lccc}
\hline & & N treatment & \\
Parameter & & HN & LN \\
\cline { 2 - 3 } Nitrate & $\mathrm{mg} \mathrm{m}^{-2}$ & $22 \mathrm{~b}$ & $26 \mathrm{a}$ \\
Soluble protein & $\mathrm{mg} \mathrm{m}^{-2}$ & $885 \mathrm{a}$ & $447 \mathrm{~b}$ \\
PEPC & $\mathrm{mg} \mathrm{m}^{-2}$ & $85 \mathrm{a}$ & $39 \mathrm{~b}$ \\
PPDK & $\mathrm{mg} \mathrm{m}^{-2}$ & $68 \mathrm{a}$ & $33 \mathrm{~b}$ \\
Rubisco & $\mathrm{mg} \mathrm{m}^{-2}$ & $355 \mathrm{a}$ & $170 \mathrm{~b}$ \\
$\mathrm{~N}_{\text {TH }}$ & $\mathrm{mg} \mathrm{m}^{-2}$ & $775 \mathrm{a}$ & $452 \mathrm{~b}$ \\
$\mathrm{~N}_{\mathrm{b}}$ & $\mathrm{mg} \mathrm{m}^{-2}$ & $107 \mathrm{a}$ & $101 \mathrm{a}$ \\
$\mathrm{N}_{\mathrm{h}}$ & $\mathrm{mg} \mathrm{m}^{-2}$ & $668 \mathrm{a}$ & $351 \mathrm{~b}$ \\
$\mathrm{~N}_{\mathrm{cW}}$ & $\mathrm{mg} \mathrm{m}^{-2}$ & $243 \mathrm{a}$ & $158 \mathrm{~b}$ \\
$\mathrm{~N}_{\mathrm{a}}$ & $\mathrm{mg} \mathrm{m}^{-2}$ & $112 \mathrm{a}$ & $55 \mathrm{~b}$ \\
\hline
\end{tabular}

Data are the means for the 2 years. Numbers followed by different letters indicate significant differences $(P<0.05)$. Soluble protein included PEPC, PPDK, and Rubisco. Abbreviations were listed in Table 1.
(Figure 5). There were no significant differences in DPSII and ETR between $\mathrm{N}$ treatment (Figure 6).

\section{DISCUSSION}

As is well documented, low-N stress causes stunted plant growth by reducing leaf expansion and $P_{\mathrm{n}}$ (Radin and Boyer, 1982; Snir and Neumann, 1997; Gastal and Lemaire, 2002; Jovanovic et al., 2004; KavanovA et al., 2008). Reduction in leaf expansion (leaf area) helps sustain leaf $\mathrm{N}$ concentration, thereby contributing to the maintenance of $P_{\mathrm{n}}$ (Radin and Boyer, 1982; Gastal and Lemaire, 2002) this seems to be especially true in N-efficient maize genotypes (McCullough et al., 1994). Under the experimental conditions of our study, $\mathrm{N}$ deficiency caused a relative reduction of $36 \%$ in ear-leaf leaf area index (data not shown) and 38\% in SLN, from $2.48 \mathrm{~g} \mathrm{~m}^{-2}$ under HN treatment to $1.55 \mathrm{~g} \mathrm{~m}^{-2}$ under $\mathrm{LN}$ treatment. $P_{\mathrm{n}}$, however, was not significantly affected. Thus, PNUE was greatly increased, by 54\%, under the LN treatment. According to Sinclair and Horie (1989), for each $\mathrm{N}$ allocation to leaves, an optimum $\mathrm{N}$ content exists to maximize crop biomass production. The optimal SLN for maximum $P_{\mathrm{n}}$ has been reported to be approximately 1.5 in field-grown maize (McCullough et al., 1994; Muchow and Sinclair, 1994; Paponov et al., 2005; Vos et al., 2005), which fits well with the value obtained under LN treatment in the present study. A higher PNUE enables maize plants to use $\mathrm{N}$ efficiently for biomass production and to increase $\mathrm{N}$ use efficiency (Table 2). A genotypic difference in PNUE has in fact been observed in maize, with $\mathrm{N}$-efficient genotypes having higher PNUE than inefficient ones (McCullough et al., 1994; Paponov and Engels, 2003; Echarte et al., 2008; Chen et al., 2014). This variation suggests that genetic improvement of PNUE is possible, and elucidation of the physiological mechanism underlying high PNUE is therefore essential. Because the high PNUE observed under LN treatment contributed to a decrease in SLN rather than an increase in $P_{\mathrm{n}}$, within-leaf optimization of $\mathrm{N}$ allocation potentially explains high PNUE.

In accord with previous studies (Pons and Westbeek, 2004; Ding et al., 2005a), LN treatment led to reduced total Chl, Chl $a$ and Chl $b$ contents (Figure 5). A reduction in Chl, together with an increase in zeaxanthin formation and the capacity for excitation energy dissipation in PSII (Khamis et al., 1990; Lu et al., 2001), are believed to be strategies for protection of PSII function (Khamis et al., 1990). The lower capacity of $P_{\mathrm{n}}$ under low-N conditions means that the greater excess of excitation energy may potentially lead to increased susceptibility of PSII to photo-inhibition (Ramalho et al., 1997; Grassi et al., 2001; Lu et al., 2001). Although the degree of low-N stress in our study was insufficient to reduce leaf $P_{\mathrm{n}}$, the leaves responded by reducing $\mathrm{Chl}$ content to avoid excess production of excitation energy. The change in $\mathrm{N}$ distribution within thylakoids was consistent with this change in Chl. Although $\mathrm{N}_{\mathrm{TH}}$ in the LN treatment was less than that in the $\mathrm{HN}$ treatment (Table 4), the percentage of $\mathrm{N}$ allocated to thylakoids was similar between $\mathrm{N}$ rates $(30-31 \%$; Figure 1). These values are close to those uncovered by Makino et al. (2003), who reported that $34 \%$ of leaf $\mathrm{N}$ was allocated to 
thylakoids in their studied maize plants. There are two types of thylakoid $\mathrm{N}$, namely that associated with bioenergetics such as the electron transport chain and photophosphorylation, and $\mathrm{N}$ involved in the light-harvesting complex. Further analysis indicated that the distribution of $\mathrm{N}$ between these two thylakoid categories differed between $\mathrm{N}$ treatments. In particular, relatively more $\mathrm{N}$ of thylakoid was allocated into biogenetics than into light harvesting under LN compared with the HN treatment (Figures 1 and 4). In fact, absolute $\mathrm{N}$ content devoted to bioenergetics was similar under the $\mathrm{LN}$ and $\mathrm{HN}$ treatment (Table 4). This proved that leaf prioritization for stabilization of electron transfer photophosphorylation under low- $\mathrm{N}$ stress and thus maximization of quantum yield (Khamis et al., 1990; Lu and Zhang, 2000; Lu et al., 2001; Tóth et al., 2002; Antal et al., 2010). This is supported by the finding that $\Phi_{\text {PSII }}$ and ETR were not different between $\mathrm{N}$ treatments (Figure 6). On the other hand, a reduction in the allocation of $\mathrm{N}$ to the light-harvesting complex should help control excess electron production. In $\mathrm{C}_{3}$ plants, Hikosaka and Terashima (1995) used models to calculate the nitrogen allocation among photosynthetic components at different incident photon flux density and $\mathrm{N}$ levels. They found that the relative amount of $\mathrm{N}$ in Rubisco decreases with decreases in leaf $\mathrm{N}$, while that in electron transport components, coupling factor and Calvin cycle enzymes increases (apart from Rubisco, PSI, and PSII). And the relative amount of $\mathrm{N}$ partitioned into Chl-protein complexes (PSI, PSII, and LHCII) remained almost constant with decreasing leaf $\mathrm{N}$.

Low $\mathrm{N}$ supply caused a relative reduction in both soluble protein per unit leaf- $\mathrm{N}$ content (from 2.23 to $1.80 \mathrm{~g} \mathrm{~g}^{-1} \mathrm{~N}$ ) and the percentage of total soluble protein- $\mathrm{N}$ in total leaf $\mathrm{N}$ (from 36\% to 30\%; Figure 3). This latter value is in good agreement with the results of Makino et al. (2003), who reported that $33 \%$ of leaf $\mathrm{N}$ was allocated to soluble protein. Among soluble proteins, Rubisco, PEPC, and PPDK are key enzymes involved in $\mathrm{C}_{4}$ photosynthesis. Sugiyama et al. (1984) found

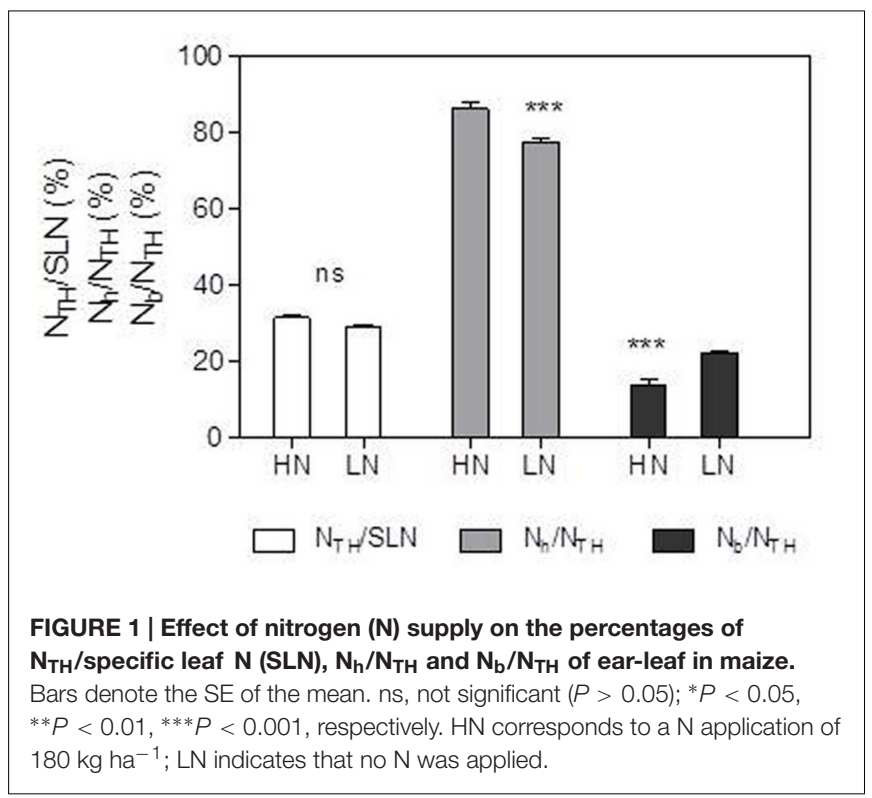

that the proportions of Rubisco, PEPC, and PPDK in soluble protein were, respectively, about 35,8 , and $6 \%$ in leaves of maize seedlings grown under optimal conditions. At near-optimal growth conditions in our study, Rubisco, PEPC, and PPDK constituted approximately 40,10 , and $8 \%$ of soluble protein and $14.5,3.5$, and $2.8 \%$ of total leaf $N$, respectively (Table 4; Figure 3 ). Under LN treatment, the contents of Rubisco, PEPC, and PPDK per unit leaf area were reduced by 52,54 , and 51\%, respectively (Table 4; Figure 4). In addition, their corresponding proportions of total leaf $\mathrm{N}$ declined by 24,28 , and $23 \%$ under low $\mathrm{N}$ condition (Figure 3). These responses are not consistent with what found in the developed young leaves at seedling stage. In these leaves, low $\mathrm{N}$ availability preferentially reduced PEPC, followed by PPDK, with less effect on Rubisco. As a result, the proportion of Rubisco to PEPC and PPDK increases concomitantly (Sugiyama et al., 1984; Sugiharto et al., 1990). The reason for the inconsistency may be that, in young leaves at seedling stage, the nitrogendependent changes in the amount of Rubisco, PEPC, and PPDK in plants is mainly due to changes in the rates of protein synthesis (Sugiharto et al., 1990). While in the senescing leaves such as the ear-leaf in grain filling phase in the present study, change of these proteins should be mainly due to the breakdown of these proteins (Feller et al., 2008; Masclaux-Daubresse et al., 2010). In fact, in the old leaves of maize seedlings, $\mathrm{N}$ starvation reduced Rubisco, PEPC, and PPDK to a similar extent (Sugiharto et al., 1990). The above data suggest that, in $\mathrm{N}$-deficient functional leaves at seedling stage, maize maintains photosynthesis system probably by downregulating $\mathrm{CO}_{2}$-trapping mediated by PEPC and PPDK but maintaining $\mathrm{CO}_{2}$ conversion mediated by Rubisco. This is supported by Usuda (1984) who found that Rubisco but not PEPC may be rate-limiting factors for photosynthesis in maize seedling. Similarly, Usuda et al. (1984) find that, among ten $\mathrm{C}_{4}$ plants, photosynthetic rate was strongly correlated to Rubisco but not PEPC activity. While in the mature leaves in which a large amount of soluble proteins (including Rubisco, PEPC, and PPDK) accumulate (Table 4, Sugiharto et al., 1990; Lawlor, 2002), the amount of Rubisco, PEPC, and PPDK might not be the limiting factors for maintaining photosynthesis. Other factors,

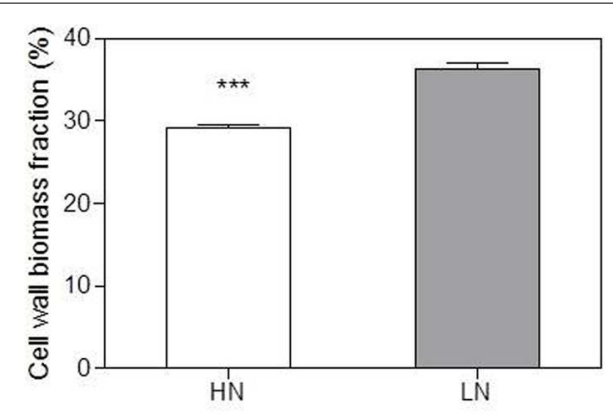

FIGURE 2 | Effect of nitrogen (N) supply on the cell wall biomass fraction of ear-leaf in maize. Bars denote the SE of the mean. ns, not significant $(P>0.05) ;{ }^{*} P<0.05,{ }^{* *} P<0.01,{ }^{* * *} P<0.001$, respectively. $\mathrm{HN}$ corresponds to a $\mathrm{N}$ application of $180 \mathrm{~kg} \mathrm{ha}^{-1}$; $\mathrm{LN}$ indicates that no $\mathrm{N}$ was applied. 
such as electron transfer and quantum yield as suggested above might become essential for $\mathrm{CO}_{2}$ assimilation.

Yin et al. (2011) found that maize plants grown under low $\mathrm{N}$ had lower bundle-sheath conductance ( $\mathrm{g}_{\mathrm{bs}}$ ) for $\mathrm{CO}_{2}$, which contributed to their lower $\mathrm{CO}_{2}$ leakage and photorespiration. The lower $g_{b s}$ value under low $\mathrm{N}$ was presumably associated with an increase in wall thickness of the bundle-sheath cells (Leegood, 2002; Yin et al., 2011). In the present study, the fraction of cell wall biomass was increased by low- $\mathrm{N}$ stress, probably because of enhanced carbohydrate accumulation in leaves and allocation to cell walls (Schlüter et al., 2012). Although $\mathrm{N}_{\mathrm{cw}}$ decreased under LN treatment, the percentage of $\mathrm{N}_{\mathrm{cw}}$ in total leaf $\mathrm{N}$ remained unchanged (Table 4; Figure 3). This result suggests that $\mathrm{N}$ allocation to cell walls is preserved to maintain normal cell wall properties under LN conditions, thus possibly contributing to a decrease in $g_{b s}$ and maintenance of $P_{\mathrm{n}}$ in bundle sheath cells to the greatest extent possible.

Leaf proteins and cell walls together constituted 72 and $78 \%$ of leaf $\mathrm{N}$ in $\mathrm{LN}$ and $\mathrm{HN}$-grown plants, respectively (Figure 3). The remaining $\mathrm{N}$ would have included nucleic acids and defensive compounds such as alkaloids, cyanogenic glycosides, and nicotine (Onoda et al., 2004; Takashima et al., 2004). Nucleic acids account for approximately 5-15\% of leaf $\mathrm{N}$ (Chapin et al., 1986; Chapin, 1989; Evans, 1989b), while defensive compounds constitute up to about 5\% (Höft et al., 1996; Burns et al., 2002). N investment into these $\mathrm{N}$ components was maintained under low$\mathrm{N}$ conditions (Figure 3 ), suggesting these components are crucial for normal physiological activity under low-N stress.

Yield increase during Green Revolution is largely driven by the increases of the portion of biomass partition into grains. Most recently, it is supposed that redesigning photosynthesis is essential to sustainably meet global food and bioenergy demand, that is, increase photosynthesis with less input of land, water, nutrients etc. (Evans, 2013; Ort et al., 2015). New models are proposed to increase the efficiency of light capture, light energy conversion, carbon capture and conversion, possibly by fast developing genetic engineering technologies (Ort et al., 2015). During grain filling phase in field grown maize, $\mathrm{N}$ is continuously remobilized from the leaves and transported to grains for protein synthesis. In such a situation, the current results suggest that sufficient $\mathrm{N}$ allocation into bioenergetics is essential to maintain leaf photosynthesis with reducing SLN. That means, under normal $\mathrm{N}$ supplies, the amount of Rubisco, PEPC, and PPDK might be beyond what is required for achieving the potential $P_{\mathrm{n}}$ (Sugiyama et al., 1984; Tazoe et al., 2005; Uribelarrea et al., 2009). Therefore, if grain protein is not a concern, N partitioning into Chl, light-harvesting proteins, and soluble protein (including Rubisco, PEPC, and PPDK) etc., can be substantially reduced to improve $\mathrm{N}$ utilization efficiency. On the other hand, the current data also imply that, to further increase the potential of leaf photosynthesis at optimal growth condition, genetic modification of Rubisco, PEPC, and PPDK should focus more on their activity, but not their synthesis. For example, Uribelarrea et al. (2009) found a positive linear correlation between Rubisco initial activity and net photosynthesis in maize at grain filling stage. Ghannoum et al. (2005) concluded that superior N-use efficiency of NADP$\mathrm{ME}$ relative to NAD-ME grasses is related to faster Rubisco turn over. Further studies are required to verify these hypotheses.

\section{CONCLUSION}

Optimization of $\mathrm{N}$ allocation within maize leaves may be an adaptive mechanism to maximize $\mathrm{N}$ utilization for photosynthesis, thus increasing grain yield per unit of plant $\mathrm{N}$ during the grain-filling stage under a low-N environment. Although ear-leaf SLN was reduced by $38 \%$ under LN treatment, $P_{\mathrm{n}}$ was hardly affected and PNUE was increased by $54 \%$. Under low-N stress, maize plants tended to invest relatively more $\mathrm{N}$ into bioenergetics to sustain electron transport. In

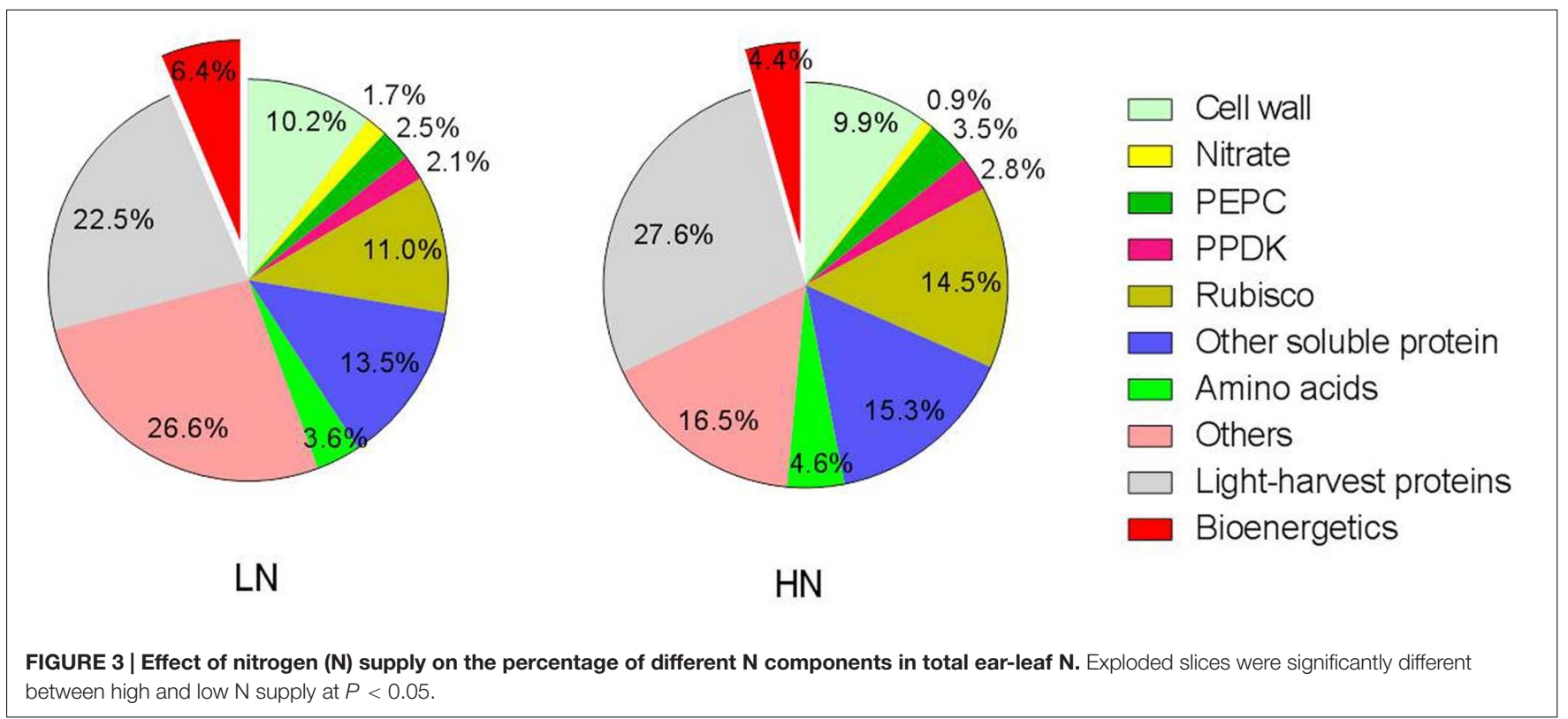




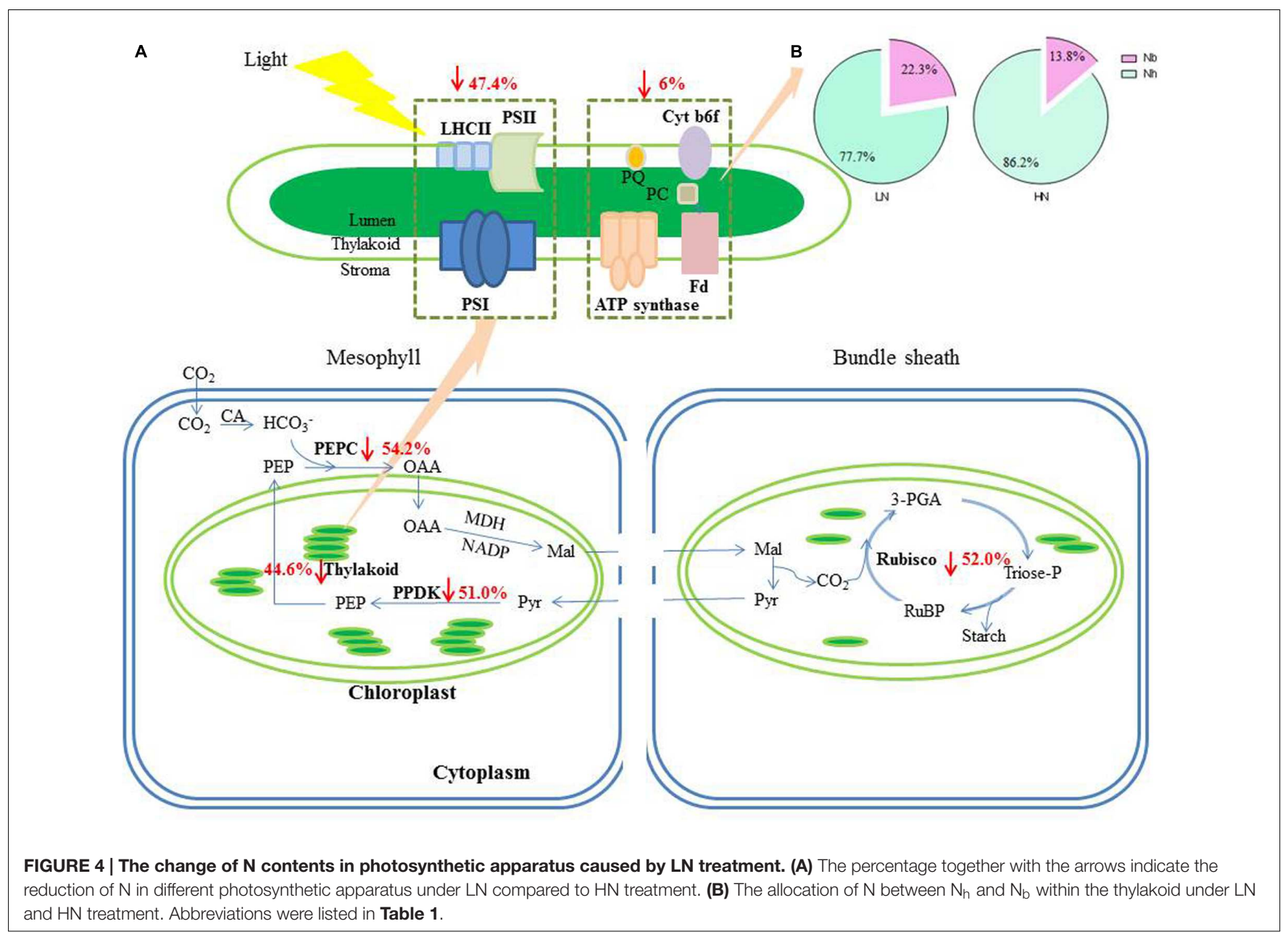

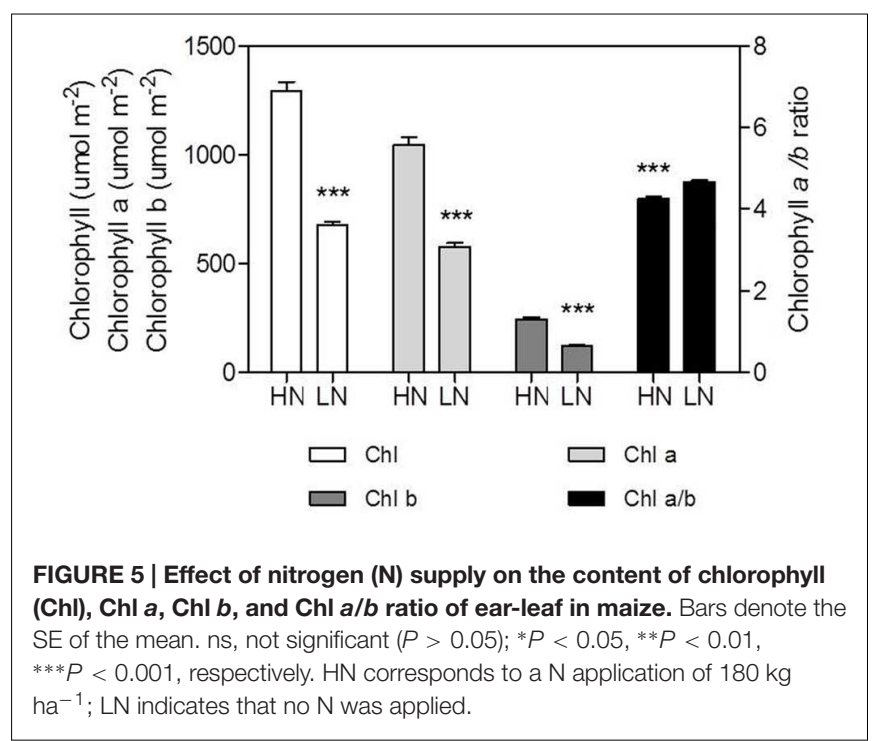

contrast, Chl and light-harvesting proteins were reduced to control excess electron production. Under low $\mathrm{N}$, total soluble protein per unit leaf area and the proportion of $\mathrm{N}$ allocated

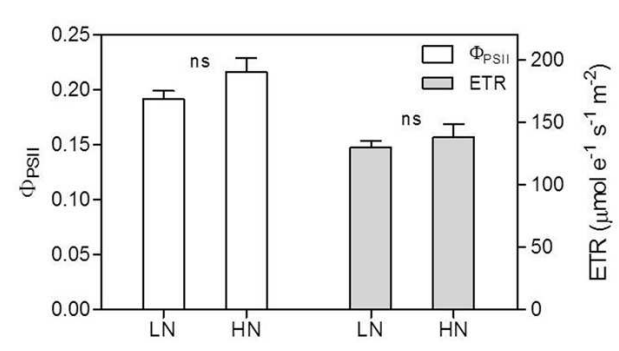

FIGURE 6 | Effect of nitrogen (N) supply on the actual quantum yield of PSII photochemistry ( $\Phi$ PSII) and electron transport rate (ETR) of ear-leaves in maize. Bars denote the SE of the mean. ns, not significant $(P>0.05) ;{ }^{*} P<0.05,{ }^{* *} P<0.01,{ }^{* * *} P<0.001$, respectively. $\mathrm{HN}$ corresponds to a $\mathrm{N}$ application of $180 \mathrm{~kg} \mathrm{ha}^{-1}$; LN indicates that no $\mathrm{N}$ was applied.

to soluble protein were reduced by 49 and $19 \%$, respectively, suggesting that a large portion of soluble protein served as $\mathrm{N}$ storage reservoirs to be later remobilized to grain for protein synthesis in $\mathrm{HN}$ treatment. Among the three major enzymes-Rubisco, PEPC, and PPDK - the percentage of leaf $\mathrm{N}$ 
allocated to Rubisco, PEPC, and PPDK declined 24, 28, and 23\%, respectively, under LN treatment. These suggested that these proteins are present in even greater excess for photosynthesis under normal $\mathrm{N}$ supply. Our findings suggest that PNUE and whole-plant $\mathrm{N}$ utilization efficiency can be increased in maize by optimizing $\mathrm{N}$ partitioning within leaves.

\section{AUTHOR CONTRIBUTIONS}

XM collected the samples, analyzed the samples, and drafted the manuscript. QC made a contribution to acquisition and analysis of the work. FC and LY made a contribution to design of the work. GM made a contribution to design of the work, analysis and revise the manuscript.

\section{REFERENCES}

Antal, T., Mattila, H., Hakala-Yatkin, M., Tyystjärvi, T., and Tyystjärvi, E. (2010). Acclimation of photosynthesis to nitrogen deficiency in Phaseolus vulgaris. Planta 232, 887-898. doi: 10.1007/s00425-010-1227-5

Antonietta, M., Fanello, D. D., Acciaresi, H. A., and Guiamet, J. J. (2014). Senescence and yield responses to plant density in stay green and earliersenescing maize hybrids from Argentina. Field Crops Res. 155, 111-119. doi: 10.1016/j.fcr.2013.09.016

Birch, C. J., Vos, J., and Van der Putten, P. (2003). Plant development and leaf area production in contrasting cultivars of maize grown in a cool temperate environment in the field. Eur. J. Agron. 19, 173-188. doi: 10.1016/S11610301(02)00034-5

Brown, R. H. (1978). A difference in $\mathrm{N}$ use efficiency in $\mathrm{C}_{3}$ and $\mathrm{C}_{4}$ plants and its implications in adaptation and evolution. Crop Sci. 18, 93-98. doi: 10.2135/cropsci1978.0011183X001800010025x

Burns, A. E., Gleadow, R. M., and Woodrow, I. E. (2002). Light alters the allocation of nitrogen to cyanogenic glycosides in Eucalyptus cladocalyx. Oecologia 133, 288-294. doi: 10.1007/s00442-002-1055-9

Cataldo, D. A., Maroon, M., Schrader, L. E., and Youngs, V. L. (1975). Rapid colorimetric determination of nitrate in plant tissue by nitration of salicylic acid. Commun. Soil Sci. Plant Anal. 6, 71-80. doi: 10.1080/00103627509366547

Chapin, F. S. III. (1989). The cost of tundra plant structures: evaluation of concepts and currencies. Am. Nat. 133, 1-19. doi: 10.1086/284898

Chapin, F. S. III Shaver, G. R., and Kedrowski, R. A. (1986). Environmental controls over carbon, nitrogen and phosphorus fractions in Eriophorum vaginatum in Alaskan tussock tundra. J. Ecol. 74, 167-195.

Chen, X., Chen, F., Chen, Y., Gao, Q., Yang, X., Yuan, L., et al. (2013). Modern maize hybrids in Northeast China exhibit increased yield potential and resource use efficiency despite adverse climate change. Global Change Biol. 19, 923-936. doi: $10.1111 /$ gcb.12093

Chen, Y., Xiao, C., Chen, X., Li, Q., Zhang, J., Chen, F., et al. (2014). Characterization of the plant traits contributed to high grain yield and high grain nitrogen concentration in maize. Field Crops Res. 159, 1-9. doi: $10.1016 /$ j.fcr.2014.01.002

Ding, L., Wang, K. J., Jiang, G. M., Biswas, D. K., Xu, H., Li, L. F., et al. (2005a). Effects of nitrogen deficiency on photosynthetic traits of maize hybrids released in different years. Ann. Bot. 96, 925-930. doi: 10.1093/aob/mci244

Ding, L., Wang, K. J., Jiang, G. M., Liu, M. Z., Niu, S. L., and Gao, L. M. (2005b). Post-anthesis changes in photosynthetic traits of maize hybrids released in different years. Field Crops Res. 93, 108-115. doi: 10.1016/j.fcr.2004. 09.008

Drouet, J., and Bonhomme, R. (1999). Do variations in local leaf irradiance explain changes to leaf nitrogen within row maize canopies? Ann. Bot. 84, 61-69. doi: 10.1006/anbo. 1999.0890

\section{ACKNOWLEDGMENT}

We gratefully acknowledge the financial support of the National Science Foundation of China (Nos. 31272233 and 31421092).

\section{SUPPLEMENTARY MATERIAL}

The Supplementary Material for this article can be found online at: http://journal.frontiersin.org/article/10.3389/fpls.2016.00699

FIGURE S1 | Effect of nitrogen (N) supply on the amounts of phosphoenolpyruvate carboxylase (PEPC), pyruvate orthophosphate dikinase (PPDK), and the Rubisco large subunit (LSU) in maize ear-leaves as revealed by sodium dodecyl sulfate-polyacrylamide gels electrophoresis (Tazoe et al., 2005). Leaves were sampled during the grain-filling stage in maize grown under 0 and $180 \mathrm{~kg} \mathrm{ha}^{-1}$ supplied N. Four biological replicates are shown per $\mathrm{N}$ treatment.

Dwyer, L. M., and Stewart, D. W. (1986). Effect of leaf age and position on net photosynthetic rates in maize (Zea mays L.). Agric. For. Meteorol. 37, 29-46. doi: 10.1016/0168-1923(86)90026-2

Echarte, L., Rothstein, S., and Tollenaar, M. (2008). The response of leaf photosynthesis and dry matter accumulation to nitrogen supply in an older and a newer maize hybrid. Crop Sci. 48, 656-665. doi: 10.2135/cropsci2007.06.0366

Evans, J. R. (1989a). Photosynthesis and nitrogen relationships in leaves of C3 plants. Oecologia 78, 9-19. doi: 10.1007/BF00377192

Evans, J. R. (1989b). "The allocation of protein nitrogen in the photosynthetic apparatus: costs, consequences and control," in Photosynthesis, ed. W. R. Brigs (New York. NY: Alan R. Liss, Inc.),

Evans, J. R. (2013). Improving photosynthesis. Plant Physiol. 162, 1780-1793. doi: 10.1104/pp.113.219006

Feller, U., Iwona Anders, I., and Mae, T. (2008). Rubiscolytics: fate of Rubisco after its enzymatic function in a cell is terminated. J. Exp. Bot. 59, 1615-1624. doi: $10.1093 / \mathrm{jxb} / \mathrm{erm} 242$

Fukayama, H., Tsuchida, H., Agarie, S., Nomura, M., Onodera, H., Ono, K., et al. (2001). Significant accumulation of C4-specific pyruvate, orthophosphate dikinase in a C3 plant, rice. Plant Physiol. 127, 1136-1146. doi: 10.1104/pp.010641

Gastal, F., and Lemaire, G. (2002). N uptake and distribution in crops: an agronomical and ecophysiological perspective. J. Exp. Bot. 53, 789-799. doi: $10.1093 /$ jexbot/53.370.789

Ghannoum, O., Evans, J. R., Chow, W. S., Andrews, T. J., Conroy, J. P., and Von Caemmerer, S. (2005). Faster Rubisco is the key to superior nitrogen-use efficiency in NADP-malic enzyme relative to NAD-malic enzyme C4 grasses. Plant Physiol. 137, 638-650. doi: 10.1104/pp.104.054759

Grassi, G., Colom, M. R., and Minotta, G. (2001). Effects of nutrient supply on photosynthetic acclimation and photoinhibition of one-year-old foliage of Picea abies. Physiol. Plant. 111, 245-254. doi: 10.1034/j.1399-3054.2001.1110217.x

Hawkesford, M. J. (2012). Improving Nutrient use Efficiency in Crops. New York City, NY: Wiely. doi: 10.1002/9780470015902.a0023734

Hikosaka, K. (2014). Optimal nitrogen distribution within a leaf canopy under direct and diffuse light. Plant Cell Environ. 37, 2077-2085. doi: $10.1111 /$ pce. 12291

Hikosaka, K., and Terashima, I. (1995). A model of the acclimation of photosynthesis in the leaves of C3 plants to sun and shade with respect to nitrogen use. Plant Cell Environ. 18, 605-618. doi: 10.1111/j.13653040.1995.tb00562.x

Hirel, B., Le Gouis, J., Ney, B., and Gallais, A. (2007). The challenge of improving nitrogen use efficiency in crop plants: towards a more central role for genetic variability and quantitative genetics within integrated approaches. J. Exp. Bot. 58, 2369-2387. doi: 10.1093/jxb/erm097

Höft, M., Verpoorte, R., and Beck, E. (1996). Growth and alkaloid contents in leaves of Tabernaemontana pachysiphon Stapf (Apocynaceae) as influenced 
by light intensity, water and nutrient supply. Oecologia 107, 160-169. doi: 10.1007/BF00327899

Jovanovic, Z., Djakovic, T., Stikic, R., Prokic, L., and Sukalovic, V. H. (2004). Effect of $\mathrm{N}$ deficiency on leaf growth and cell wall peroxidase activity in contrasting maize genotypes. Plant Soil 265, 211-223. doi: 10.1007/s11104-005-0503-9

KavanovA, M., Lattanzi, F. A., and Schnyder, H. (2008). Nitrogen deficiency inhibits leaf blade growth in Lolium perenne by increasing cell cycle duration and decreasing mitotic and post-mitotic growth rates. Plant Cell Environ. 31, 727-737. doi: 10.1111/j.1365-3040.2008.01787.x

Khamis, S., Lamaze, T., Lemoine, Y., and Foyer, C. (1990). Adaptation of the photosynthetic apparatus in maize leaves as a result of nitrogen limitation relationships between electron transport and carbon assimilation. Plant Physiol. 94, 1436-1443. doi: 10.1104/pp.94.3.1436

Kosgey, J. R., Moot, D. J., Fletcher, A. L., and McKenzie, B. A. (2013). Dry matter accumulation and post-silking $\mathrm{N}$ economy of 'stay-green'maize (Zea mays L.) hybrids. Eur. J. Agron. 51, 43-52. doi: 10.1016/j.eja.2013.07.001

Lawlor, D. W. (2002). Carbon and nitrogen assimilation in relation to yield: mechanisms are the key to understanding production systems. J. Exp. Bot. 53, 773-787. doi: $10.1093 /$ jexbot $/ 53.370 .773$

Leegood, R. C. (2002). C 4 photosynthesis: principles of $\mathrm{CO}_{2}$ concentration and prospects for its introduction into $\mathrm{C}_{3}$ plants. J. Exp. Bot. 53, 581-590. doi: $10.1093 /$ jexbot $/ 53.369 .581$

$\mathrm{Lu}$, C., and Zhang, J. (2000). Photosynthetic $\mathrm{CO}_{2}$ assimilation, chlorophyll fluorescence and photoinhibition as affected by nitrogen deficiency in maize plants. Plant Sci. 151, 135-143. doi: 10.1016/S0168-9452(99)00207-1

Lu, C., Zhang, J., Zhang, Q., Li, L., and Kuang, T. (2001). Modification of photosystem II photochemistry in nitrogen deficient maize and wheat plants. J. Plant Physiol. 158, 1423-1430. doi: 10.1078/0176-1617-00501

Lynch, J. P. (2013). Steep, cheap and deep: an ideotype to optimize water and $\mathrm{N}$ acquisition by maize root systems. Ann. Bot. 112, 347-357. doi: $10.1093 / \mathrm{aob} / \mathrm{mcs} 293$

Makino, A., Mae, T., and Ohira, K. (1986). Colorimetric measurement of protein stained with Coomassie Brilliant Blue $\mathrm{R}$ on sodium dodecyl sulfatepolyacrylamide gel electrophoresis by eluting with formamide. Agric. Biol. Chem. 50, 1911-1912. doi: 10.1271/bbb1961.50.1911

Makino, A., Sakuma, H., Sudo, E., and Mae, T. (2003). Differences between maize and rice in $\mathrm{N}$-use efficiency for photosynthesis and protein allocation. Plant Cell Physiol. 44, 952-956. doi: 10.1093/pcp/pcg113

Makino, A., Shimada, T., Takumi, S., Kaneko, K., Matsuoka, M., Shimamoto, K., et al. (1997). Does decrease in ribulose-1, 5-bisphosphate carboxylase by antisense RbcS lead to a higher N-use efficiency of photosynthesis under conditions of saturating $\mathrm{CO}_{2}$ and light in rice plants? Plant Physiol. 114, 483-491.

Masclaux-Daubresse, C., Daniel-Vedele, F., Dechorgnat, J., Chardon, F., Gaufichon, L., and Suzuki, A. (2010). Nitrogen uptake, assimilation and remobilization in plants: challenges for sustainable and productive agriculture. Ann. Bot. 105, 1141-1157. doi: 10.1093/aob/mcq028

McCullough, D. E., Aguilera, A., and Tollenaar, M. (1994). N uptake, N partitioning, and photosynthetic N-use efficiency of an old and a new maize hybrid. Can. J. Plant Sci. 74, 479-484. doi: 10.4141/cjps94-088

Mi, G., Chen, F., Wu, Q., Lai, N., Yuan, L., and Zhang, F. (2010). Ideotype root architecture for efficient nitrogen acquisition by maize in intensive cropping systems. Sci. China Life Sci. 53, 1369-1373. doi: 10.1007/s11427-010-4097-y

Moll, R. H., Kamprath, E. J., and Jackson, W. A. (1982). Analysis and interpretation of factors which contribute to efficiency of nitrogen utilization. Agron. J. 74, 562-564. doi: 10.2134/agronj1982.00021962007400030037x

Moore, S. (1968). Amino acid analysis: aqueous dimethyl sulfoxide as solvent for the ninhydrin reaction. J. Biol. Chem. 243, 6281-6283.

Muchow, R. C., and Sinclair, T. R. (1994). Nitrogen response of leaf photosynthesis and canopy radiation use efficiency in field-grown maize and sorghum. Crop Sci. 34, 721-727. doi: 10.2135/cropsci1994.0011183X003400030022x

Onoda, Y., Hikosaka, K., and Hirose, T. (2004). Allocation of nitrogen to cell walls decreases photosynthetic nitrogen-use efficiency. Funct. Ecol. 18, 419-425. doi: 10.1111/j.0269-8463.2004.00847.x

Ort, D. R., Merchant, S. S., Alric, J., Barkan, A., Blankenship, R. E., Bock, R., et al. (2015). Redesigning photosynthesis to sustainably meet global food and bioenergy demand. Proc. Natl. Acad. Sci. U.S.A. 112, 8529-8536. doi: $10.1073 /$ pnas. 1424031112
Paponov, I. A., and Engels, C. (2003). Effect of nitrogen supply on leaf traits related to photosynthesis during grain filling in two maize genotypes with different $\mathrm{N}$ efficiency. J. Plant Nutr. Soil Sci. 166, 756-763. doi: 10.1002/jpln.200320339

Paponov, I. A., Sambo, P., Presterl, T., Geiger, H. H., and Engels, C. (2005). Grain yield and kernel weight of two maize genotypes differing in nitrogen use efficiency at various levels of nitrogen and carbohydrate availability during flowering and grain filling. Plant Soil 272, 111-123. doi: 10.1007/s11104-0044211-7

Peng, L., Ma, J., Chi, W., Guo, J., Zhu, S., Lu, Q., et al. (2006). Low PSII accumulation 1 is involved in efficient assembly of photosystem II in Arabidopsis thaliana. Plant Cell 18, 955-969. doi: 10.1105/tpc.105.037689

Pons, T. L., and Westbeek, M. H. (2004). Analysis of differences in photosynthetic nitrogen-use efficiency between four contrasting species. Physiol. Plant. 122, 68-78.

Poorter, H., and Evans, J. R. (1998). Photosynthetic nitrogen-use efficiency of species that differ inherently in specific leaf area. Oecologia 116, 26-37. doi: $10.1007 / \mathrm{s} 004420050560$

Porra, R. J., Thompson, W. A., and Kriedemann, P. E. (1989). Determination of accurate extinction coefficients and simultaneous equations for assaying chlorophylls a and b extracted with four different solvents: verification of the concentration of chlorophyll standards by atomic absorption spectroscopy. Biochim. Biophys. Acta 975, 384-394. doi: 10.1016/S0005-2728(89)80347-0

Radin, J. W., and Boyer, J. S. (1982). Control of leaf expansion by nitrogen nutrition in sunflower plants role of hydraulic conductivity and turgor. Plant Physiol. 69, 771-775. doi: 10.1104/pp.69.4.771

Ramalho, J. C., Pons, T. L., Groeneveld, H. W., and Nunes, M. A. (1997). Photosynthetic responses of Coffea arabica leaves to a short-term high light exposure in relation to $\mathrm{N}$ availability. Physiol. Plant. 101, 229-239. doi: 10.1111/j.1399-3054.1997.tb01841.x

Sage, R. F., and Pearcy, R. W. (1987). The nitrogen use efficiency of C3 and C4 plants II. Leaf nitrogen effects on the gas exchange characteristics of Chenopodium album (L.) and Amaranthus retroflexus (L.). Plant Physiol. 84, 959-963. doi: 10.1104/pp.84.3.954

Sage, R. F., and Pearcy, R. W. (2000). The Physiological Ecology of C4 Photosynthesis. Berlin: Springer, 497-532.

Sanderson, J. B., Daynard, T. B., and Tollenaar, M. (1981). A mathematical model of the shape of corn leaves. Can. J. Plant Sci. 61, 1009-1011. doi: 10.4141/cjps 81-151

Schlüter, U., Mascher, M., Colmsee, C., Scholz, U., Bräutigam, A., Fahnenstich, H., et al. (2012). Maize source leaf adaptation to nitrogen deficiency affects not only nitrogen and carbon metabolism but also control of phosphate homeostasis. Plant Physiol. 160, 1384-1406. doi: 10.1104/pp.112.204420

Schmitt, M. R., and Edwards, G. E. (1981). Photosynthetic capacity and nitrogen use efficiency of maize, wheat, and rice: a comparison between $C_{3}$ and $C_{4}$ photosynthesis. J. Exp. Bot. 32, 459-466. doi: 10.1093/jxb/32.3.459

Sinclair, T. R., and Horie, T. (1989). Leaf nitrogen, photosynthesis, and crop radiation use efficiency: a review. Crop Sci. 29, 90-98. doi: 10.2135/cropsci1989.0011183X002900010023x

Snir, N., and Neumann, P. M. (1997). Mineral nutrient supply, cell wall adjustment and the control of leaf growth. Plant Cell Environ. 20, 239-246. doi: 10.1046/j.1365-3040.1997.d01-57.x

Sugiharto, B., Miyata, K., Nakamoto, H., Sasakawa, H., and Sugiyama, T. (1990). Regulation of expression of carbon-assimilating enzymes by nitrogen in maize leaf. Plant Physiol. 92, 963-969. doi: 10.1104/pp.92.4.963

Sugiyama, T. (1973). Purification, molecular, and catalytic properties of pyruvate phosphate dikinase from the maize leaf. Biochemistry 12, 2862-2868. doi: 10.1021/bi00739a014

Sugiyama, T., Mizuno, M., and Hayashi, M. (1984). Partitioning of nitrogen among ribulose-1, 5-bisphosphate carboxylase/oxygenase, phosphoenolpyruvate carboxylase, and pyruvate orthophosphate dikinase as related to biomass productivity in maize seedlings. Plant Physiol. 75, 665-669. doi: 10.1104/pp.75.3.665

Takashima, T., Hikosaka, K., and Hirose, T. (2004). Photosynthesis or persistence: nitrogen allocation in leaves of evergreen and deciduous Quercus species. Plant Cell Environ. 27, 1047-1054. doi: 10.1111/j.1365-3040.2004. 01209.x

Tazoe, Y., Noguchi, K. O., and Terashima, I. (2005). Effects of growth light and nitrogen nutrition on the organization of the photosynthetic apparatus in leaves 
of a C4 plant, Amaranthus cruentus. Plant Cell Environ. 29, 691-700. doi: 10.1111/j.1365-3040.2005.01453.x

Tollenaar, M., and Lee, E. A. (2006). Dissection of physiological processes underlying grain yield in maize by examining genetic improvement and heterosis. MAYDICA 51, 399.

Tóth, V. R., Mészáros, I., Veres, S., and Nagy, J. (2002). Effects of the available nitrogen on the photosynthetic activity and xanthophyll cycle pool of maize in field. J. Plant Physiol. 159, 627-634. doi: 10.1078/0176-1617-0640

Uedan, K., and Sugiyama, T. (1976). Purification and characterization of phosphoenolpyruvate carboxylase from maize leaves. Plant Physiol. 57, 906910. doi: 10.1104/pp.57.6.906

Uribelarrea, M., Crafts-Brandner, S. J., and Below, F. E. (2009). Physiological $\mathrm{N}$ response of field-grown maize hybrids (Zea mays L.) with divergent yield potential and grain protein concentration. Plant Soil 316, 151-160. doi: 10.1007/s11104-008-9767-1

Usuda, H. (1984). Variations in the photosynthesis rate and activity of photosynthetic enzymes in maize leaf tissue of different ages. Plant Cell Physiol. 25, 1297-1301.

Usuda, H., Ku, M. S. B., and Edwards, G. E. (1984). Rates of photosynthesis relative to activity of photosynthetic enzymes, chlorophyll and soluble protein content among ten C4 species. Austral. J. Plant Physiol. 11, 509-517. doi: 10.1071/PP9840509

Vos, J., Van Der Putten, P., and Birch, C. J. (2005). Effect of nitrogen supply on leaf appearance, leaf growth, leaf nitrogen economy and photosynthetic capacity in maize (Zea mays L.). Field Crops Res. 93, 64-73. doi: 10.1016/j.fcr.2004. 09.013

Wang, Y., Mi, G., Chen, F., Zhang, J., and Zhang, F. (2005). Response of root morphology to nitrate supply and its contribution to nitrogen accumulation in maize. J. Plant Nutri. 27, 2189-2202. doi: 10.1081/PLN-2000 34683

Yin, X., Sun, Z., Struik, P. C., and Gu, J. (2011). Evaluating a new method to estimate the rate of leaf respiration in the light by analysis of combined gas exchange and chlorophyll fluorescence measurements. J. Exp. Bot. 62, 3489-3499. doi: 10.1093/jxb/err038

Zhang, L., Paakkarinen, V., van Wijk, K. J., and Aro, E. (1999). Co-translational assembly of the D1 protein into photosystem II. J. Biol. Chem. 274, 1606216067. doi: $10.1074 /$ jbc. 274.23 .16062

Conflict of Interest Statement: The authors declare that the research was conducted in the absence of any commercial or financial relationships that could be construed as a potential conflict of interest.

Copyright (c) $2016 \mathrm{Mu}$, Chen, Chen, Yuan and Mi. This is an open-access article distributed under the terms of the Creative Commons Attribution License (CC BY). The use, distribution or reproduction in other forums is permitted, provided the original author(s) or licensor are credited and that the original publication in this journal is cited, in accordance with accepted academic practice. No use, distribution or reproduction is permitted which does not comply with these terms. 